\title{
Play-Based Learning as An Essential Strategy to Face 21st-Century Learning
}

\author{
Sukma Shinta Yunianti \\ \{ssukmashinta@untidar.ac.id\} \\ Universitas Tidar, Magelang, Indonesia
}

\begin{abstract}
Playing is an excellent way to enhance learners' comprehension. Learning through play can be as an alternative process to enhance learners' knowledge. It allows learners to have abilities in observing, planning, memorizing, exploring, analyzing, and creating meaning. Those abilities support learners' learning process not only for their external skills such as in socialization but also their essential skills such as in improving their language abilities, working with others, and promoting creativity. This study highlights the notion of play-based learning and how this alternative learning process can be integrated into $21 \mathrm{st}$ century learning. Involvement in play encourages learners to cultivate their thinking to be critical. The play-based learning process enhances learners' outcomes academically and socially. In short, it makes learners success in facing 21 st-century learning.
\end{abstract}

Keywords: Play-based learning, 21st-century learning, Critical thinking

\section{INTRODUCTION}

The importance of play is complicated to define. In our society, a play is considered the opposite of learning. It is represented, such as, "You have to finish your task first before playing." It means that play can be done after finishing the vital work. Besides, a play is something valuable. It aims to emphasize learners' cognitive and emotional development.

Furthermore, play as an essential strategy in the learning process. It can be an alternative way to achieve learners' language knowledge and abilities. It is in line with play is essential for the development of learners' academic skills. Play-based learning means an active and purposeful play that requires physical, verbal, or mental engagement to pleasurable play that emphasizes enjoyment as a key feature. For example, how learners interact with others and perform independently is learned from their surroundings and experiences. It will significantly impact the way things are done because very learner learns differently.

Furthermore, there are many importances of play-based learning [1]. Play-based learning allows students to engage in purposeful activities. The play-based learning is defined as: 1) It is voluntary; 2) It is intrinsically motivating, it means pleasurable is not dependent on external rewards; 3) It involves some level of activity, and 4) It is distinct from other behaviors by having a make-believe quality [1] [2] [3] [4]. Besides, there are some effects of play-based learning - first, play-based learning as the media of the educational organization. Second, play-based learning as self-reflection. Third, play-based learning as physical 
development. Last, the use of play-based learning supports the promotion of socialization among the learners and the development of language.

Actually, in the 21st-century, learners must have the ability to communication, collaboration, creativity, and critical thinking. So, the learners must train their competence to develop their skills in communication, collaboration, creativity, and critical thinking. Playbased learning is one of the alternative learning processes for learners as the media to enhance their competences. There are many things that students can get in play-based learning. Playbased learning makes learners communicate with others. It also involves physical engagement, and external rewards, play to emphasize learners' cognitive and emotional development [4]. All those activities can develop the ability of the learners in the four competencies that learners must-have in the 21st-century. In short, play-based learning is very beneficial for learners in developing and mastering their competence in 21 st-century learning.

\section{METHOD}

This study used a qualitative approach to the type of library study. The type of this study contains an in-depth collection of material on one or several subjects. This study allows us to observe, plan, memorize, explore, analyze, and create something concerning 21st-century learning competence. This study not only explores what play is but also explores what kind of play that suitable to apply in enhancing learners' ability as their essential strategy to face 21 stcentury learning.

\section{RESULTS AND DISCUSSIONS}

\subsection{Play-Based Learning is Purposeful Real Learning}

21 st-century learning is a standard of learning in the 21 st-century. In the application of 21 stcentury learning, there are some outcomes that the learners must get after the learning abilities. The 21 st-century learners' results are life and career abilities, learning and innovation abilities, and information media and technology abilities. Some support systems can achieve 21 st-century outcomes. There are standards and assessments, curriculum and instruction, professional developments, and learning environments.

Related to life and career abilities, the learners must have excellent flexibility and must be adaptive. They must be initiative and self-direction. The learners also must have social and cross-cultural skills, good leadership, and responsibility. In the learning and innovation abilities, the learners must be creative. They must have excellent critical thinking and problem-solving. They must also have good communication and collaboration. In the last in the information, media, and technology abilities, they must be able to access information, media, and ICT literacy. There are many competencies that the learners must master in 21 st-century learning. The four competencies in 21st-century learning are very close to collaborating with others. In life and career abilities, the learners must have excellent flexibility and adaptivity. They must also be good at social and cultural abilities and creative. It is also for learning and innovative skills. Moreover, they also must have excellent communication and collaboration. All of those need collaboration with others. All those activities can be learned by collaborating with others. Play-based learning is very relevant to train those abilities and to make learners communicate with others well. Learners will learn about leadership and the social environment. Learners get many benefits of applying play-based learning. This kind of learning strategies is not only designed for developing specific educational purposes but also for communication abilities. The strategy is designed to attain long-term success in learners' learning process. In conclusion, 
play-based learning is very suitable to implement in developing learners' 21 st-century learning competencies.

The play takes a role in developing life competencies, creating a pleasurable activity, and concerning with the process. In line with the notion of 21 st-century learning, the learning process emphasizes on learner-centeredness. It believed that learners used their knowledge during play that leads to classification and logical thinking act [5]. Besides, play is a cognitive process where learners construct their knowledge while learning through play exploration [6]. Free play and guided play take a vital position to enhance social competence and confidence in learners' ability to manage their emotions and behaviors. Supervised play is better to use than free play in the academic field. Researchers said that play promotes language activities, abilities, and strategies [6]. Academically, play is related to the vital learning process that comprehends language competencies. Learners demonstrate their language abilities during play, and language abilities are related to the development of literacy. Also, the play gives opportunities to teach and learn a language. The guided play also supports learners by providing opportunities to explore and follow the learners' interests. The play has a specific learning goal even though free play has no particular learning purpose.

\subsection{Collaborative Abilities in Collaborative Learning}

Based on core subjects and themes of 21st-century learning, play-based learning can be used to enhance learners' life abilities. Play contributes to developing learners' academic outcomes as well as essential skills, including confidence, collaboration, communication, and creative thinking. Those competencies contribute to how the learning outcomes can be developed in the long-term. Experts suggest that success depends on abilities that include confidence (taking risks and learning from failure), collaboration (teamwork, social competence), communication (oral and written), and creative thinking. Furthermore, related to the characteristics in 21 stcentury learning, namely communication, collaboration, critical thinking, and creativity, playbased learning involves those $4 \mathrm{Cs}$ rubric performance areas. Choosing to play, learners develop their abilities in all areas, namely motoric, cognitive, social, and emotional skills. Play contributes to the development of learners' thinking and problem-solving ability. It accommodates communication, collaboration, critical thinking, and creativity. In the academic field, those 4Cs abilities are an essential thing to do. Those happen not only in the educational field but also require in the behavioral and social areas. Those happen because learners must have interactions with people, situations, and conditions of their environment. They realize that become good people in person is essential for their life. They also identify that there are different ways to solve problems because people have different views, opinions, and perspectives. Those activities require learners to understanding, analyzing, evaluating, and synthesizing their ideas and options. They encourage to share their ideas and thoughts. Those make them active during the learning process unwittingly.

For example, in creativity competence, learners identify cognitive flexibility, divergent thinking, imagination, intrinsic motivation, open-mindedness, and enjoyment of new experiences. Related to the educational field, learners have competencies in participating in creative activities, creating new content from one's idea or other references, and using newly created material to solve problems and make a decision. In creating new content of one's idea or other references needs divergent thinking, including flexibility, elaborating, fluency, and originality. Besides, the play also provides learners with opportunities to enhance their creative thinking abilities such as practicing thinking in different ways, having different perspectives to view conditions, and thinking of strategies to solve a problem. 
Also, the play enables learners to practice their language abilities they have learned and build on their vocabulary. Language competence can be built by building social relationships. Interacting with others also enables learners to enhance their communication and collaboration competencies by listening to others. The reason is interaction as one of the essential skills in supporting language. Learners who have limited opportunities for interaction will often have immature language development. Thus, it is essential to ensure each learner gets opportunities that promoting the opportunity for socialization with others. Another example, in the collaborative abilities in collaborative learning, learners must be good in collaboration with others. Collaboration enables a group to make better decisions than any one individual would on his own since it allows for the consideration of multiple perspectives. Collaboration is the joining together of numerous individuals in the service of working towards a common goal. Related to the collaborative ability, play triggers the learners to improve their skills in working effectively with teams. That is because play makes learners interact with others in some environments. It makes learners confident in the social environment.

Play-based learning also makes learners automatically giving ideas when they interact with other learners. Play-based learning is very close to flexibility. When learners play, they become flexible to do something. They practice a lot for some materials without feeling nervous and scared. In another word, play-based learning can instruct the learners to practice sociability and willingness to help make necessary compromises to accomplish a common goal. When the learners' play, they cannot be separated from the environment. They will interact with other learners in all conditions. When they play, they will meet with the other learners with a different character. So, learners can feel enjoy when they must work or building a relationship with other people to do some job. It makes learners responsible for their collaborative work.

Collaborative learning supports learners to increase their learning outcomes, enjoyment of the subject matter, self-esteem, and inclusiveness of diversity. There are many different pedagogical tools utilized in collaborative learning. Learners also consider more positive about school, subject areas, and teachers, as well as each other when they learn collaboratively. It is also synergistic with the $4 \mathrm{Cs}$ of 21 stcentury competencies. Those competencies engaged with each other and can be seen in figure 1 below. 


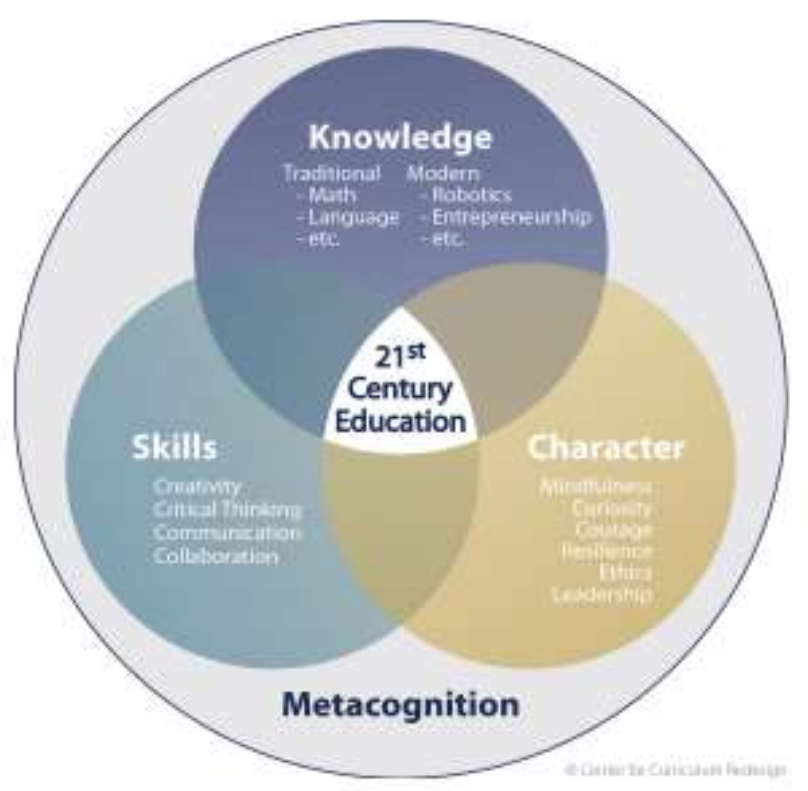

Fig.1.1 Relation between skill, knowledge, and character

\section{CONCLUSION}

Play as a cornerstone in the learning process. Play and learning cannot be separated. When learners play, they are also learning. The relation between play and learning is inextricably and intertwined. Learning through play cannot be stopped in the classroom or the house.

Furthermore, learners' thinking cannot be restricted to anything. It happens everywhere and every time. Letting learners play supports them to have a "good brain." It is because play helps them to explore, identify, negotiate, make a decision, create meaning, and take a risk. Learners learn better if they get opportunities to explore new things actively.

Furthermore, play is beneficial to learners' language abilities and supports language learning. Those competencies prepare and encourage learners to face and master 4Cs competencies firmly. Doing play gives not only learners opportunities but also benefits to be an autonomous learner.

\section{REFERENCES}

[1] E. e. a. Ali, "The Effect of Play-Based Learning on Early Childhood Education and Development," Journal of Evolution of Medical and Dental Science, doi: 10.14260/jemds/2018/1044, 2018.

[2] R. M. \&. H.-P. K. Golinkoff, "Becoming Brilliant: What ScienceTells Us Abou Raising Successful Children," American Psychological Association, vol. 3, 2016. 
[3] M. e. a. Han, "Does Play Make A Differences? How Play Intervention Affects The Vocabulary Learning of At-Risk Preschoolers.," American Journal of Play, vol. 3(1), pp. 82-105, 2010.

[4] T. \&. E. J. Paes, Developing Life Skills Through Play. Part of the Cambridge Papers in ELT Series., Cambridge: Cambridge University Press, 2019.

[5] E. \&. P. Danniels, "A. Defining Play-Based Learning.," Journal of Early Childhood Development, 2018.

[6] K. \&. C. J. Roskos, "The Play -Literacy Nexus and The Importance of Evidence-Based Techniques in the Classroom.," American Journal of Play, vol. 4, pp. 204-224, 2011.

[7] J. Piaget, Play, Dreams, and Imitation in Childhood., New York: W. W. Norton \& Company, 1962.

[8] M. \&. F. C. Bialik, Skill For The 21st Century: What Should Students Learn., Massachuttes: CCR, 2015.

[9] J. M. e. a. Zosh, "Accessing the Inaccessible: Redefining Play as a Spectrum," Frontiers in Psychology, vol. 9, p. 1124, 2018. 